\title{
Sublethal Effects of Methanolic Extract of Raphia hookeri on the Reproductive Capacity of Clarias gariepinus
}

\author{
Adedotun O. Afolayan, ${ }^{1,2}$ Temitope I. Borokini,' ${ }^{1}$ and Gloria O. Afolayan' \\ ${ }^{1}$ National Centre for Genetic Resources and Biotechnology, Moor Plantation, Oyo State, Ibadan 200001, Nigeria \\ ${ }^{2}$ Department of Zoology, University of Ibadan, Oyo State, Ibadan 200001, Nigeria \\ Correspondence should be addressed to Adedotun O. Afolayan; onoyinka@yahoo.com
}

Received 8 May 2014; Revised 8 September 2014; Accepted 13 October 2014; Published 5 November 2014

Academic Editor: Raine Kortet

Copyright ( 2014 Adedotun O. Afolayan et al. This is an open access article distributed under the Creative Commons Attribution License, which permits unrestricted use, distribution, and reproduction in any medium, provided the original work is properly cited.

Raphia hookeri fruits are used for fishing in Nigeria due to their ichthyotoxic properties. This study investigated the toxic effects of $R$. hookeri on the reproductive capacity of Clarias gariepinus. The results from both short-term (96-hour test) and long-term (3-month sublethal test) bioassays revealed a linear relationship between $R$. hookeri extract dose and negative effects on the catfish. The percentage survival of both sexes of the catfish decreased with increasing extract concentration at short-term exposure, with $\mathrm{LC}_{50}$ values of $600 \mathrm{mg} / \mathrm{L}$ and $800 \mathrm{mg} / \mathrm{L}$ for male and female, respectively. At long-term exposure, the reproductive capacity of 10-12month-old male and female brood-stocks diminished at relatively higher concentrations of $R$. hookeri fruit extract, with the gravid females producing fewer and mostly unviable eggs. The fruit extract also affected the eggs' hatchability and fry survival when the exposed gravid females were treated with pituitary hormone and sperms from unexposed males, while the exposed males were unable to sexually stimulate female brooders. Sperms and pituitary hormone from exposed males were infertile, leading to low percentage of hatched eggs and mortality of the few hatched fries within 24 hours. These results confirmed the ethnobotanical use of this fruit extract for fishing in Nigeria.

\section{Introduction}

Fish is one of the cheapest protein sources in sub-Saharan Africa [1], and the importance of fish in developing countries increased greatly after the Sahelian drought of 1971 to 1974, which decimated the cattle population and hence shot up the prices of beef [2]. Clarias gariepinus (Burchell, 1822) belongs to the family Clariidae, and is widely distributed in Nigerian waters [3]. The fish is known for its high tolerance and high survivability [4] and resilience in harsh habitat conditions [5]. There is a huge market value for the fish in Nigerian markets due to its taste [6], which resulted in the proliferation of fish farming business in Nigeria using different fish production methods. However, wild catch still remains important. In order to increase catch yields in traditional fishing, different toxic plants that can stupefy fish have been exploited $[7,8]$

Chopra et al. [9] reported at least 112 plants with poisonous effects on fish. Seigler [10] reported the piscicidal effect of some common plants of India that are frequently used in freshwater bodies against target organism while Neuwinger [11] also observed that there is a wide variety of wild and cultivated poisonous plants available to coastal fishermen for capturing fish. Most recently, Fafioye [12] reported 40 plants with piscicidal effects being used in Southwest Nigeria for fish harvesting. However, it can be expected that the use of these plants for fishing in Nigerian freshwater bodies would have negative effects on aquatic biodiversity. Several studies have shown the specific effects of plant extracts that have toxic properties: Azadirachta indica have been known to be toxic to Gambusia affinis [13]; Charkraborty et al. [14] reported that Croton tighim seeds, Millettia pachyarpa roots, Annona squamosa, Dodonaea viscosa, Camellia sinensis, and Nicotiana tabacum have some toxic properties; acute concentrations of the bark of Balanites sapida and Kigelia africana to Clarias gariepinus have been reported to cause physiological dysfunction and reduced growth [15]; Aguigwo [16] reported that cassava peel extracts caused stressed behavior in Clarias anguillaris fingerlings. 
Obuotor and Onajobi [17] reported the cytotoxic properties of $R$. hookeri fruit mesocarp.

Raphia hookeri (Raffia palm) is the largest palm in Africa and is restricted to the tropical rainforest [18]. It is one of the most economically useful plants in Africa; the trunk serves as firewood, the leaves are used for shelter and the stem produces palm sap, which is drank as beverage. The fermented sap can be distilled into alcohol or local gin [19] while the leaf petiole yields fibrous piassava. Succulent, oily larvae of weevils and beetles are obtained from infected palms and serve as delicacy. The mesocarp of the ripe fruit yields edible oil [20, 21]; however, the fruit mesocarp is also reported to have potent toxic properties [17].

Ekelemu [22] studied the toxic effects of Raphia palm pulp extracts in C. gariepinus fingerlings and showed that Raphia palm have lethal haematological effects on C. gariepinus. Furthermore, Adeogun [23] reported multiple negative biological effects of methanolic extracts of $R$. hookeri extracts on C. gariepinus includinghyperventilation, sneezing, and rapid opercula movement which was reported to be due to the damaging effects of the active component of Raphia palm (saponin) on the respiratory epithelia. Negative effects of toxicants depend on the species, sex, size, and age as well as the general health condition. In this study, we wished to investigate the effect of sublethal doses of $R$. hookeri extracts on reproductive functions of male and female catfish broodstock.

\section{Materials and Methods}

2.1. Extraction Procedure. Plant extraction followed the procedure of Adeogun et al. [24]. Air-dried and grounded fruit of $R$. hookeri $(20 \mathrm{~kg})$ was extracted by percolation using hexane $(2.13 \%$ yield) and then with methanol ( $24.93 \%$ yield). Methanolic extraction yielded more extract. The percolate was evaporated to dryness using a low-high vacuum pump that creates the required vacuum for the removal of methanol and moisture. Desiccators containing calcium chloride salts were then used to further absorb methanol and moisture from the extract. Stock solutions of the extract were prepared by dissolving $100 \mathrm{~g}$ of the extract in $10 \mathrm{~L}$ of water and from this, serial dilutions were made.

2.2. Acquisition of Test Organisms. For the bioassay, 10-12month-old male $(342.2 \pm 17.05 \mathrm{~g})$ and female brood stocks $(250 \pm 24.58 \mathrm{~g})$ of C. gariepinus were obtained from a commercial fish farm in Ibadan. They were then transported to the laboratory in well-aerated plastic containers. At the laboratory, the fish were kept in rectangular glass tanks $\left(1800 \mathrm{~cm}^{2}\right)$ throughout the experiment for easy visibility.

2.3. Acclimatization Procedure. Acclimatization of the fish samples was done for a period of 7 days. During the acclimatization period, the fish were fed once daily with a $40 \%$ protein fish-feed at the rate of 3\% body weight for adult fish/day. Well aerated dechlorinated municipal tap water was used as the holding medium (temperature $28.5 \pm 2.5^{\circ} \mathrm{C} ; \mathrm{pH}$ $7.1 \pm 0.3)$. The tank water was monitored and changed twice a week to avoid contamination. The fish were well-adapted to laboratory conditions and no death was recorded for 4 consecutive days [25].

2.4. Exposure of Test Organisms. The fish were weighed and the average weight obtained for the male fish was $342.2 \mathrm{~g}$ and $250.0 \mathrm{~g}$ for females. Feeding was discontinued 24 hours prior to the commencement of the experiment and during the 96hours range-finding test [25]. A preliminary range-finding test was carried out for 96 hours (4 days) using diluted extract concentrations ranging from $250 \mathrm{mg} / \mathrm{L}-1200 \mathrm{mg} / \mathrm{L}$. This was done to determine the concentration at which the toxicant was lethal to the test organisms. Distribution of fish into tanks was done and 4 fish were kept in each experimental tank. The control fish tank was not exposed to the R. hookeri treatment (only water). Standard procedures for bioassay as described by APHA [26] were used with slight modifications (12 $\mathrm{g}$ of fish to $1 \mathrm{~L}$ of water for brooders). Fish behavioral changes were reported at $1,2,3,4,8,16,48,72$, and 96 hours. Dead fish were promptly removed from the experimental tank. Dose response for mortality response was analyzed by the Probit method [27]. The index of toxicity measurement derived from this analysis was 96 -hour $\mathrm{LC}_{50}$ values (median lethal concentration that causes 50\% response (mortality) in exposed organisms).

2.5. Toxicity Experimental Procedure. Fractions of 1/5, 1/10, and $1 / 15$ of the $\mathrm{LC}_{50}$ were used in a 30 -day sublethal exposure for male and 20 days for female brood stocks. Two replicates of each fish sex (4 fish per tank) were kept in each concentrations prepared. For the male brood stocks, the concentrations used were 40,60 , and $120 \mathrm{mg} / \mathrm{L}$ while for the female, 53.3, 80, and $160 \mathrm{mg} / \mathrm{L}$ were used. Control experiments with no extract exposure were also set up for each case.

2.6. Fertilization Procedure. After the exposure for 30 days, $R$. hookeri exposed male catfish were randomly selected and their sperm sacs were collected and kept in labeled clean containers with $9 \%$ saline solution. It had been observed that the life-span of fish sperm varies with the substrate within which the testes are kept and sperm also live longer periods in lower temperatures [28]. These containers were then kept in the refrigerator to extend their lifespan according to Nahagama [29] and Viveen et al. [30]. The pituitary gland of each exposed male was also removed and gently grounded in a mortar before adding $9 \%$ saline solution.

Then, $0.1 \mathrm{~mL}$ of this preparation, which contained pituitary hormone $(\mathrm{PH})$, was injected into equivalent weighted unexposed female fish (control). These females were kept for 12 hours to aid the maturation of the eggs. After 12 hours, the eggs were stripped and the stored sperm milt from the exposed male fish was used in the fertilization of these stripped eggs by gentle mixing in a plastic bowl containing $9 \%$ saline solution to ensure longer sperm viability. Stripping of eggs for female brooders was done by applying gentle pressure to the abdominal area [30]. The fertilized eggs were then spread in the nursery bowls containing tiny shredded ropes to simulate nursery grounds, with water running in and out 
TABLE 1: Morphological and behavioural responses of C. gariepinus in test solution.

\begin{tabular}{lll}
\hline Studied characteristic & Observations on fishes prior to exposure & Observations on fish after exposure \\
\hline Skin colour & Black dorsally and grayish white ventrally & $\begin{array}{l}\text { Colour changed to a mottled grayish colour dorsally } \\
\text { with dark spots occurring all over body }\end{array}$ \\
\hline Response to stimuli & Rapid response to external stimuli that is touching & Relatively sluggish with occasional spiral movement \\
\hline Swimming & Normal swimming (dorsal side up) & $\begin{array}{l}\text { Alternate swimming on the lateral side and rapid } \\
\text { and erratic swimming behavior }\end{array}$ \\
\hline Breathing mechanisms & Normal breathing & Gasping for breath \\
\hline Opercula movement & Normal opercula movement & Rapid opercula movement \\
\hline
\end{tabular}

of the bowls to ensure constant aeration as well as to avoid contamination.

2.7. Estimation of Brood-Stock Fertility. The total number of stripped eggs was counted during distribution into nursery tanks and recorded. Continuous observation of the nursery tanks revealed that hatching occurred about 15 hours after induced fertilization. The unhatched eggs were siphoned out, counted, and recorded to determine percentage hatchability. Egg viability rates were determined based on the percentage number of hatched eggs [31], where

Egg viability rate

$$
=\frac{\text { Number of hatched eggs }}{\text { Total number of eggs in a batch }} \times 100 \text {. }
$$

The same process was repeated for the exposed female fish using the unexposed control male fish $\mathrm{PH}$ preparations and sperm. Control experiments involved the use of unexposed male fish $\mathrm{PH}$ and sperm on unexposed female fish.

2.8. Data Analysis. Toxicity measurement index was $\mathrm{LC}_{50}$, which is the median lethal concentration that causes $50 \%$ response (mortality) in exposed organisms. The $\mathrm{LC}_{50}$ was determined by Probit method of analysis for the male and female brood-stocks [27]. Data on fish wet weight, egg count, and number of hatchlings across exposure concentrations were analyzed by one-way ANOVA (differences between means were considered significant when $P<0.05$ ).

\section{Results}

3.1. General Observation. The morphological and behavioral responses of the fish prior and after introduction to the plant extracts are shown in Table 1.

All exposed fish demonstrated rapid and erratic swimming behavior on introduction of diluted concentrations of the extract. Other observations included being stunned (for 20-30 seconds), gasping for breath, rapid opercula movement, and emission of froth from the mouth. Behavioral changes were less apparent at lower $R$. hookeri concentrations (data not presented as they were not quantified). The fishes were noted to swim away from point of plant extract administration; they appeared stunned for a period of 30 seconds. After 24 hours, fish gradually became sluggish, especially in the highest concentrations with their mouth agape. None of these responses was seen in control groups.

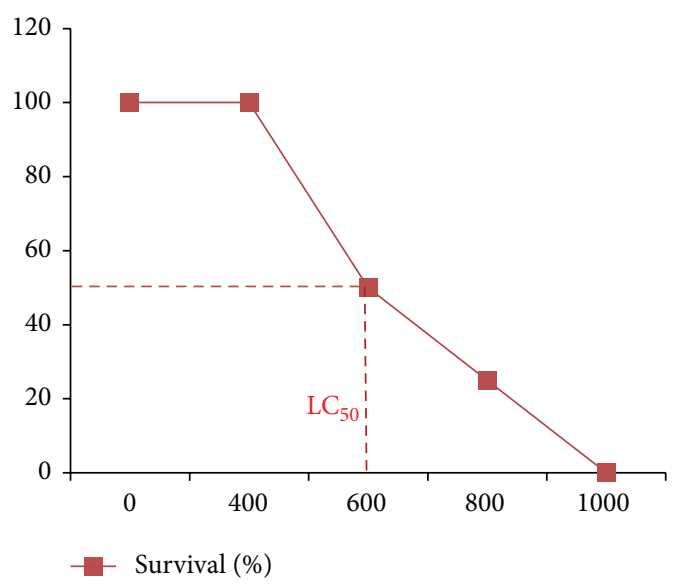

FIGURE 1: Determination of median lethal concentration $\left(\mathrm{LC}_{50}\right)$ of methanolic extract of $R$. hookeri by arithmetic graphic method for the male brood-stock of C. gariepinus.

3.2. Mortality Response. The results also indicated increased mortality rate with increasing concentrations of $R$. hookeri methanolic extracts. Dead specimens had increased mucus secretions. For the male brood-stock, first death was recorded at 42 hour time point in the highest concentration $(1000 \mathrm{mg} / \mathrm{L})$. By 92 hours, all the fish in this group were dead (Tables 2(a) and 2(b)). For the female brood-stock, first death was recorded at 28 hours in the highest concentration $(1200 \mathrm{mg} / \mathrm{L})$ and by 96 hours, $75 \%$ of the fish in the highest concentration were dead (Tables 2(a) and 2(c)). There was no mortality in the lowest concentrations for both the male $(400 \mathrm{mg} / \mathrm{L})$ and the female fish $(600 \mathrm{mg} / \mathrm{L})$ (Table 2(a), Figures 1 and 2).

Furthermore, it was observed that exposing C. gariepinus to increasing doses of $R$. hookeri methanolic extracts sharply reduced either viability of sperm or production of $\mathrm{PH}$ or both in exposed male brood-stock. This conclusion is based on indirect observation from the performed long-term bioassay. Number of unhatched eggs from control females treated with $\mathrm{PH}$ and sperm taken from exposed males was used to evaluate this effect. The eggs originating from control fish had the best viability score $(96.46 \%$ and $94.42 \%)$, while eggs originating from exposed males scored poorly $(0.21 \%, 0.41 \%, 20.09 \%$, $22.51 \%$, 32.34\%, and 33.37\%) (Table 3, Figure 3).

Table 4 shows the negative effect of the increasing doses of $R$. hookeri extracts on egg production and quality from exposed female C. gariepinus brood-stock. Prolonged periods 
TABLE 2: (a) Effects of different $R$. hookeri methanolic extract concentrations on male and female brood stock of C. gariepinus. (b) Time dependence of the toxicity of different $R$. hookeri methanolic extract concentrations on male brood stock of C. gariepinus over 96 hours. (c) Time dependence of the toxicity of different $R$. hookeri methanolic extract concentrations on female brood stock of $C$. gariepinus over 96 hours.

(a)

\begin{tabular}{lcccc}
\hline \multirow{2}{*}{ Concentration $(\mathrm{mg} / \mathrm{L})$} & \multicolumn{2}{c}{ Number of survivors } & \multicolumn{2}{c}{ M survival } \\
\hline Control & Male & Female & 100 & 100 \\
400 & 4 & 4 & 100 & $\mathrm{n} / \mathrm{a}$ \\
600 & 4 & $\mathrm{n} / \mathrm{a}$ & 50 & 100 \\
800 & 2 & 4 & 25 & 50 \\
1000 & 1 & 2 & 0 & 25 \\
1200 & 0 & 1 & $\mathrm{n} / \mathrm{a}$ & 25 \\
\hline
\end{tabular}

Male $\mathrm{LC}_{50}=600 \mathrm{mg} / \mathrm{L} ;$ Female $\mathrm{LC}_{50}=800 \mathrm{mg} / \mathrm{L}$.

n/a: not applicable.

(b)

\begin{tabular}{lcccccccccc}
\hline Concentration (mg/L) & \multicolumn{9}{c}{ Mean \% mortality over exposure period } \\
& \multicolumn{1}{c}{ Time (hours) } \\
\hline & 1 & 2 & 4 & 8 & 16 & 24 & 48 & 72 & 96 \\
1000 & 0 & 0 & 0 & 0 & 0 & 0 & 100 & 100 & 100 \\
800 & 0 & 0 & 0 & 0 & 0 & 0 & 75 & 75 & 75 \\
600 & 0 & 0 & 0 & 0 & 0 & 0 & 50 & 50 & 50 \\
400 & 0 & 0 & 0 & 0 & 0 & 0 & 0 & 0 & 0 \\
0 & 0 & 0 & 0 & 0 & 0 & 0 & 0 & 0 & 0 \\
\hline
\end{tabular}

(c)

\begin{tabular}{|c|c|c|c|c|c|c|c|c|c|}
\hline \multirow[t]{2}{*}{ Concentration $(\mathrm{mg} / \mathrm{L})$} & \multicolumn{9}{|c|}{$\begin{array}{c}\text { Mean \% mortality over the exposure period } \\
\text { Time (hours) }\end{array}$} \\
\hline & 1 & 2 & 4 & 8 & 16 & 24 & 48 & 72 & 96 \\
\hline 1200 & 0 & 0 & 0 & 0 & 0 & 0 & 75 & 75 & 75 \\
\hline 1000 & 0 & 0 & 0 & 0 & 0 & 0 & 75 & 75 & 75 \\
\hline 800 & 0 & 0 & 0 & 0 & 0 & 0 & 50 & 50 & 50 \\
\hline 600 & 0 & 0 & 0 & 0 & 0 & 0 & 0 & 0 & 0 \\
\hline 0 & 0 & 0 & 0 & 0 & 0 & 0 & 0 & 0 & 0 \\
\hline
\end{tabular}

TABLE 3: Effect of pituitary gland preparation and sperm from exposed C. gariepinus male brood-stock on eggs' fertilization and hatchability.

\begin{tabular}{|c|c|c|c|c|c|}
\hline Conc. (mg/L) & Replicates & $\begin{array}{l}\text { Weight of exposed male } \\
\text { broods }(\mathrm{g})\end{array}$ & $\begin{array}{c}\text { Total number of } \\
\text { hatched eggs }\end{array}$ & $\begin{array}{l}\text { Total number of } \\
\text { unhatched eggs }\end{array}$ & $\%$ viability \\
\hline 0 & $\mathrm{C} 1$ & 296.0 & 5073 & 300 & 96.42 \\
\hline 0 & $\mathrm{C} 2$ & 302.3 & 6050 & 222 & 96.46 \\
\hline 40 & R1A & 124.0 & 1743 & 3647 & 32.34 \\
\hline 40 & R1B & 374.4 & 2422 & 4835 & 33.37 \\
\hline 40 & $\mathrm{R} 2 \mathrm{~A}$ & 220.5 & 728 & 2896 & 20.09 \\
\hline 40 & $\mathrm{R} 2 \mathrm{~B}$ & 279.0 & 1405 & 4836 & 22.51 \\
\hline 60 & $\mathrm{R} 1 \mathrm{~A}$ & 498.7 & 28 & 13176 & 0.21 \\
\hline 60 & $\mathrm{R} 1 \mathrm{~B}$ & 449.5 & 0 & 10980 & 0 \\
\hline 60 & $\mathrm{R} 2 \mathrm{~A}$ & 368.0 & 20 & 4812 & 0.41 \\
\hline 60 & $\mathrm{R} 2 \mathrm{~B}$ & 431.5 & 0 & 5260 & 0 \\
\hline 120 & $\mathrm{R} 1 \mathrm{~A}$ & 299.0 & 0 & 4055 & 0 \\
\hline 120 & R1B & 299.0 & 0 & 4055 & 0 \\
\hline 120 & $\mathrm{R} 2 \mathrm{~A}$ & 376.6 & 0 & 3405 & 0 \\
\hline 120 & $\mathrm{R} 2 \mathrm{~B}$ & 376.6 & 0 & 3405 & 0 \\
\hline
\end{tabular}

Note: Weight of the unexposed female fish used for fertilization ranged from $179 \mathrm{~g}$ to $320 \mathrm{~g}$ with a mean weight of $248.7 \mathrm{~g}$. 
TABLE 4: Effect of $R$. hookeri methanolic extracts on egg production and quality in exposed female C. gariepinus.

\begin{tabular}{|c|c|c|c|c|c|}
\hline Conc $(\mathrm{mg} / \mathrm{L})$ & Replicates & $\begin{array}{l}\text { Weight of exposed } \\
\text { female broods (g) }\end{array}$ & Total number of eggs & $\begin{array}{c}\text { Total number of } \\
\text { hatched eggs }\end{array}$ & $\%$ viability \\
\hline 0.0 & $\mathrm{C} 1$ & 230.0 & 2415 & 1950 & 80.75 \\
\hline 0.0 & $\mathrm{C} 2$ & 243.0 & 2114 & 1665 & 78.76 \\
\hline 53.3 & $\mathrm{R} 1$ & 149.0 & 1893 & 1243 & 65.66 \\
\hline 53.3 & $\mathrm{R} 2$ & 237.0 & 2748 & 1742 & 63.39 \\
\hline 80 & $\mathrm{R} 1 \mathrm{~A}$ & 215.5 & 2850 & 35 & 1.23 \\
\hline 80 & $\mathrm{R} 1 \mathrm{~B}$ & 240.0 & 2114 & 0 & 0 \\
\hline 80 & $\mathrm{R} 2$ & 220.5 & 2453 & 0 & 0 \\
\hline 160 & $\mathrm{R} 1$ & 280.5 & 2275 & 0 & 0 \\
\hline 160 & $\mathrm{R} 2$ & 224.0 & 2850 & 0 & 0 \\
\hline
\end{tabular}

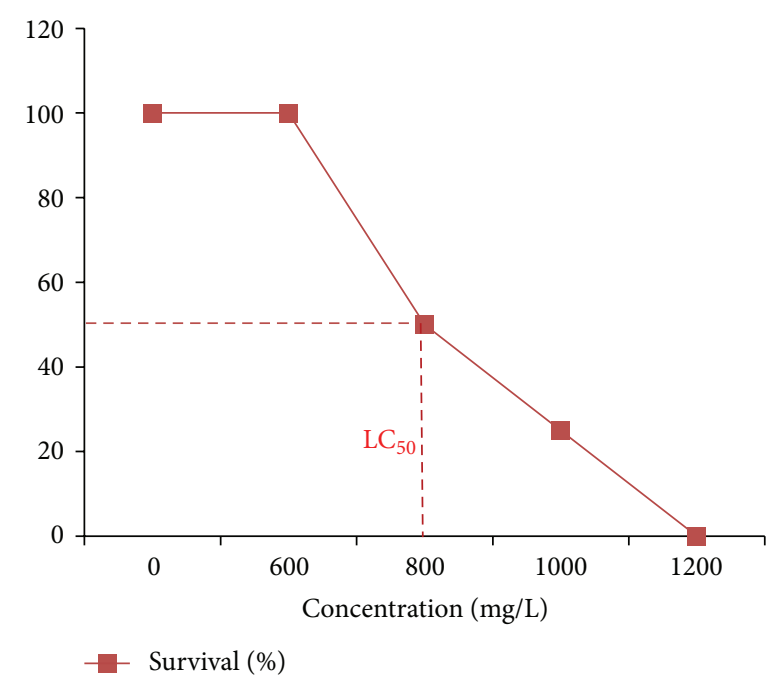

FIGURE 2: Determination of median lethal concentration $\left(\mathrm{LC}_{50}\right)$ of methanolic extract of $R$. hookeri by arithmetic graphic method for the female brood-stock of C. gariepinus.

of hatching were recorded and this increased with increase in exposure concentrations. Egg maturation was observed to occur at about 15 hours. There was delay in egg maturation (15 hours rather than the normal 10-12 hours) of the unexposed female injected with the pituitary hormone of exposed males. Significantly $(P<0.05)$ lower values were recorded for the total number of eggs that hatched from control exposures to the highest exposure. The highest exposure concentrations prevented egg viability in exposed fish as there were no hatchlings (0\%) in this exposure concentration (Tables 3 and 4).

Furthermore, the weight of C. gariepinus males exposed to $R$. hookeri methanolic extracts ranged from $124.0 \mathrm{~g}$ to $498.7 \mathrm{~g}$ (Table 3 ), while the average weight of the unexposed male fish was $626.5 \mathrm{~g}$ (Table 4).

\section{Discussions}

The reproductive output of a species is an integral endpoint in fish toxicology studies and an important aspect of risk assessment for aquatic ecosystems [32]. Survival of a species is highly dependent on the reproductive success of

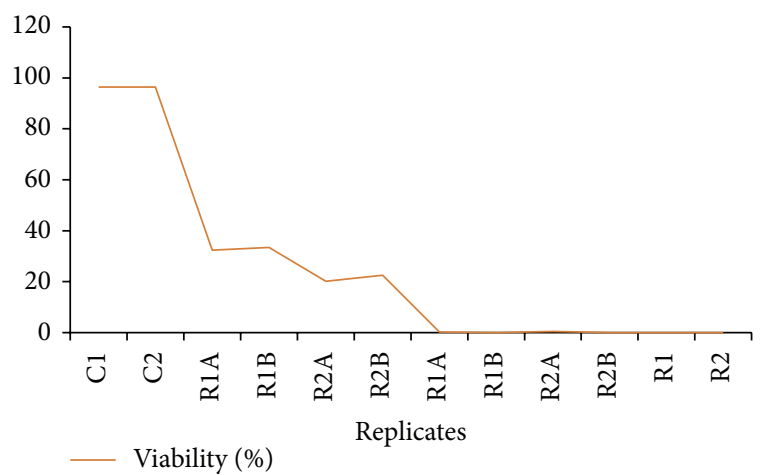

Figure 3: Percentage viability of eggs from female brood stock of C. gariepinus in different concentrations of $R$. hookeri methanolic extracts.

the species in question and for economically relevant species; water quality monitoring is necessary to aid evaluation of challenges posed by incidence of pollution [33]. Behavioral responses to poor water quality in exposed C. gariepinus brood-stock, is an indication of the toxic effect of the extract of the botanical. Consequently, it is evident from the results obtained that an increase in the concentration of $R$. hookeri methanolic extract gave rise to a series of morphological and behavioral responses from the exposed mud-catfish ( $C$. gariepinus). These responses were found to be concentrationdependent. The different stressful conditions observed in this study could be due to the negative effects of the extract on the general physiology of the test organism. The gasping for breath resulted in the continuous darting up and down in the test-water and prolonged stays at the water surface. Similarly, gasping for breath and rapid opercula movement reported in this study may be due to the damaging effect of the saponins contained in $R$. hookeri extract on fish gill epithelia. This observation is coherent with the report of Adeogun [34] that saponins are present in $R$. hookeri and it causes hyperventilation, coughing/sneezing, rapid opercula movement, and mortality in mud-catfish. The observation also agrees with the report of Roy et al. [35] that saponins are highly toxic to fish because of their damaging effect on the respiratory epithelia. The froth produced from the mouth of the test organisms confirms the presence of saponin as an 
active component of $R$. hookeri. This is due to the fact that Raphia-saponin 1 that is found in $R$. hookeri fruit belongs to a group of triterpenoid glycoside saponins, which have a distinctive foaming characteristic resulting from the combination of the nonpolar sapogenin and their water soluble side chain [36]. The resulting irritation and impairment of the respiratory epithelia will reduce the capacity of fish gill epithelia for diffusion of oxygen across the membrane [37]. According to Adeogun [23, 34], the continuous exposure of such fish to saponins-rich pollutants as is found in this study plant and some others used in capturing fish by local fisherfolks, asphyxiation (resulting in death) may occur. This is mainly due to increase in permeability of the membranes of the red blood cells (RBC), which leads to their destruction and consequently causes the hemoglobin to be released into the blood stream (hemolysis) [34]. As a result, the oxygen carrying capacity of RBCs within the organism circulatory system will be reduced. He et al. [38] confirmed that the saponins derived from the seed of Camellia oleifera may induce sneezing due to the stimulation of the nasal mucous membrane. Other observations such as color changes, sluggish and occasional spiral movement, alternate swimming on the lateral side, and rapid and erratic swimming behavior are additional effects resulting from the discomfort that the exposed test organisms were experiencing during the duration of the exposure. The different behavioral responses of the fish can also have a response to a nervous reaction of the fish to the extract (Table 1). Though this study was not designed to determine the effects on the nervous system, Thomas's [39] study comparatively linked such responses to the effect of toxicant on the cholinesterase activity in various parts of the nervous system. Also Quist [40] agrees with these observations in his study using O. niloticus exposed to Piper guineense. Similarly, Onwubuya [41] recorded similar responses with juveniles of $C$. gariepinus exposed to the aqueous extract of $R$. hookeri.

These deviations from normal behavior in fish were further confirmed when such responses were not observed in the control setup with no extract. According to Matthiessen and Logan [42] as well as Scott and Crossman [43], fish behavior is an endpoint that is not often used in toxicological assessment in spite of the fact that this parameter has the potential for use in toxicological studies as a sensitive indicator of reproductive impairment or other expressions of toxicity. Little et al. [44] observed that behavioral changes in fish occur 75\% earlier than the onset of significant mortality in fish. Some other authors have reported similar observations in different fish species exposed to nonbotanical materials. For example, Adeogun and Victor [45] reported uncoordinated swimming movement, hyperventilation, coughing, and occasional darting movement in their study of Clarias gariepinus exposed to industrial effluent. Similarly, Srivastava et al. [46] reported hyperexcitation, convulsions and rapid opercula movement in Labeo rohita and Channa punctatus exposed to paper mill effluent. Also, Pathan et al. [47] observed hyperexcitation, erratic swimming, convulsions, and jerky movement in Rasbora daniconius exposed to paper mill effluent. Consistent with these reports are temporary loss of equilibrium, hyperventilation, and hyperactivity in juvenile members of the same species (C. gariepinus) exposed to textile industry effluent [48].

The mean 96-hour $\mathrm{LC}_{50}$ value of $600 \mathrm{mg} / \mathrm{L}$ and $800 \mathrm{mg} / \mathrm{L}$ obtained for adult male and female brood-stock of the mudcatfish to the methanolic extract (Tables 2(a)-2(c); Figures 1 and 2) in this study was lower than $1590 \mathrm{mg} / \mathrm{L}$ recorded by Onwubuya [41] for mud-catfish juveniles using aqueous extract. This indicates that the active ingredients, though polar, were extracted more effectively by methanol than water. The values however were less (for male brood-stock) and equal (for female brood-stock) to the values obtained by Adeogun et al. [24] for aqueous extract of $R$. hookeri. The different $\mathrm{LC}_{50}$ values recorded for the different sexes used showed that tolerance to the toxicant differs from one sex to the other and it is lower in the male fish than the female. This agrees with the observation of Fryer and Illis [49]. Similarly, according to Parish [50], organisms differ in their susceptibility to toxicant. Rand and Petrocelli [51] related these differences to accessibility rates, patterns of metabolisms, and excretion mechanisms as well as genetic composition. Comparing with other studies with toxicants other than botanicals, the $96 \mathrm{~h} \mathrm{LC}_{50}$ value reported in this study is higher than that of Vanerker et al. [52] for physicochemically treated herbal pharmaceutical effluent $\left(96 \mathrm{~h} \mathrm{LC}_{50} ; 35.00-\right.$ $41.00 \%$ ) on Lebistes reticulatus and $20.06 \%$ for juvenile $C$. gariepinus exposed to textile industry effluent. However, higher $\mathrm{LC}_{50}$ value is expected in adult C. gariepinus because the magnitude of toxic effect is directly proportional to corporal surface/body weight of organisms and advancement in physiology may confer better adaptation/coping strategies to environmental stressors in adult fish than juvenile/fingerlings fish [53].

The mottled skin color and poor outlook of C. gariepinus may be results of depressed feeding or starvation in fish during the exposure period. According to McCue [54], starvation can be referred to as a biological condition wherein a postabsorptive animal, otherwise willing or able to eat, is unable to do so as a result of some external influence such as anthropogenic disturbance. Severe anthropogenic disturbance among other factors like long-term ecological change can lead to long and frequent bouts of starvation. Despite the continuous use of energy for the purpose of survival, most animals do not process food all the time, hence leaving them dependent on endogenous physiological fuels for important processes such as survival and reproduction [45, 55-58]. In other words, situations such as change in water quality due to the introduction of botanicals into water for harvesting by artisanal fisher-folks, or as the case applies in this study, can induce starvation leading to reliance on endogenous fuel, hence disrupting the balance between the body mass and energy flux within the organism. Exposures of these catfish to $R$. hookeri extract could have resulted in poor water quality as evidenced by the gasping for breath and occasional darting up and down the water column which may be due to low dissolved oxygen in exposure concentrations with the exception of the control.

According to Adeogun and Victor [45], reproductive success is a key factor in determining species survival. Reproductive impairment in fish by a variety of xenobiotics 
has been well reported [32,59-65] and may manifest in adults in form of decreasing quality and/or quantity of gametes, which in turn may affect fertilization success, embryonic development, larval viability, and subsequently species fitness and survival [45]. Lahnsteiner and Patarnello [66] and Bonnet et al. [67] are of the opinion that the representative criterion of the quality of a batch of eggs produced during spawning is the proportion of those eggs which successfully complete development into the next distinct biological stage of its species. For this study, significant decreases $(P<$ 0.05 ) in number of hatched eggs and percentage viability of eggs with increase in concentration was observed. Decreased egg production was observed also in different studies carried out by other authors using different pollutants apart from botanicals [32, 45, 62, 63, 68-72]. Ankley et al. [32] reported a significant decrease in fecundity of the fathead minnow (Pimephales promelas) exposed to multiple point discharges from eleven Canadian industry effluents and concluded that egg production was negatively affected at concentrations of effluent lower than approximately half the effluent concentrations that negatively impacted in vitro steroid production indicating that variations in egg production may be a cheaper and early indicator of fish response to environmental stressors. The highest concentration in this study prevented egg viability as there were no hatchlings at this concentration. This indicates reproductive failure and a negative reproductive end point at concentrations that did not affect fish survival. Rickwood et al. [62] exposed mature adult fathead minnow to bleached Kraft pulp mill effluents and reported that egg production was completely halted by one of the effluents used in the 11-mill survey from Jackfish bay in which effluent concentration did not exceed $40 \%$. Onsite exposures were subsequently used to test the effects of various process streams within the mill effluent before secondary treatment and the combined alkaline stream caused decreased spawning events and decreased egg production [62].

The results of the breeding indicated that egg maturation of the normal unexposed female injected with the pituitary hormone of exposed males took place at about 15 hours rather than the normal 10-12 hours. The delay in egg maturation could be attributed to the negative impact of the exposure to $R$. hookeri extract. Though this is not conclusive, it could be as a result of loss of nervous coordination which could have further led to disruption in the endocrine system. According to Robinson [68], the reproductive behavior of many fish is influenced by the senses through their perception of environmental changes. He further stated that this could lead to impairment of several endocrine glands and in turn, these could act on ovaries and testes. From his observations, it is obvious that there is high interdependence between the nervous and endocrine systems. As such, these two systems often act together. This implies that anything affecting one will consequently affect the other. Furthermore, the induction of the unexposed female brood-stocks with the pituitary hormone of exposed male brood-stocks showed that the viability of the eggs produced decreased with the increase in concentrations of the extract to which the male has been exposed to (Table 4; Figure 3). Hence, it can be inferred that
TABLE 5: Summary of the analysis of variance ( $t$-test) of mean percentage viability of exposed C. gariepinus brood stock.

\begin{tabular}{lccc}
\hline $\begin{array}{l}\text { Concentration of } \\
\text { extract }(\mathrm{mg} / \mathrm{L})\end{array}$ & Df & t-test value & $\begin{array}{c}\text { Sig }(2 \text { tailed }) \\
P<0.05\end{array}$ \\
\hline R40 & 2 & 11.649 & 0.007 \\
R60 & 2 & 89.316 & 0.000 \\
R53.3 & 2 & 10.007 & 0.010 \\
R80 & 2 & 76.147 & 0.000 \\
\hline
\end{tabular}

the extract had a significant effect on the pituitary hormone of the male brood-stocks. Also, the exposed female mudcatfish's result showed that despite the induction of these exposed brood-stocks with the pituitary hormone of unexposed male brood-stocks, the eggs they produced were immature and nonviable (Table 4). This also indicated that the concentration of the extract, to which the female broodstocks had been exposed, significantly affected the maturation of eggs. This is corroborated by the observation of Lamai et al. [73], who states that there is a possibility that dieldrin accumulation in the central nervous system could block or disrupt the hypothalamic to pituitary link. The hypothalamic to pituitary link is the section that usually controls egg development and maturation. Also, Sorensen [74] noted that exposures to toxicants like copper have systemic effects as well as reproductive effects such as blockage of spawning activities, reduced egg production, deformity of fry, and low ability of the young to survive.

The $t$-test values all indicated significant response at $P<$ 0.05 except for R40 (Table 5) and this further corroborates the fact that there is possibility of acute or sublethal effects of the different concentrations of the $R$. hookeri extract. It further confirms that higher concentrations of the extract could negatively impact the viability of the eggs and quality of the sperm of the different exposed brood-stocks.

\section{Conclusion}

This study has demonstrated that exposure of C. gariepinus male and female brood-stock to the methanolic extract of $R$. hookeri resulted in reproductive impairment in catfish that were exposed to lower concentrations and reproductive failure in the highest exposure concentration. Furthermore, it is also possible that the disruption of nervous coordination occurs. This may depend on the concentration of the extract used and the length of time that the test organisms are exposed to the toxic botanical extract. However from this study, it was observed that higher concentration induced greater impact on the catfish than lower concentrations. Thus, it could be said that frequent exposures to lower concentrations may not cause any permanent damage to reproductive ability in fish due to biodegradability of most botanicals. But, if the fish are exposed to higher concentrations of the botanical as seen in this study, more deleterious effects could occur. These effects may linger for a longer period of time before the population is restored back to a healthy life. Thus, the negative effects that arise, such as on their reproductive 
ability, as a result of such exposures could lead to a more great impact on these fish biodiversity as well as the nontarget aquatic organisms.

\section{Conflict of Interests}

The authors declare that there is no conflict of interests regarding the publication of this paper.

\section{References}

[1] S. O. E. Sadiku and A. A. Oladimeji, "Relationship of proximate composition of Lates niloticus (L), Synodontis schall," Research Communications, vol. 3, no. 1, pp. 29-40, 1991.

[2] O. O. Fawole, M. A. Ogundiran, T. A. Ayandiran, and O. F. Olagunju, "Proximate and mineral composition in some selected fresh water fishes in Nigeria," Internet Journal of Food Safety, vol. 9, pp. 52-55, 2007.

[3] O. A. Fagbenro, "The dietary habits of clarid catfish Heterobranchus bidorsalis (Geoffery st. Hilaria) in Owerri, Southern Nigeria," Tropical Zoology, vol. 5, pp. 11-17, 1992.

[4] M. A. Ogundiran, O. O. Fawole, S. O. Adewoye, and T. A. Ogundiran, "Pathological lesions in the gills of Clarias gariepinus exposed to sublethal concentrations of soap and detergent effluents," Journal of Cell and Animal Biology, vol. 3, pp. 78-82, 2009.

[5] H. Hogendoorn, "Controlled propagation of the African catfish, Clarias lazera (C\& V). I. Reproductive biology and field experiments," Aquaculture, vol. 17, no. 4, pp. 323-333, 1979.

[6] O. Kori-Siakpere and E. O. Ubogu, "Sublethal haematological effects of zinc on the freshwater fish, Heteroclarias sp. (Osteichthyes: Clariidae)," African Journal of Biotechnology, vol. 7, no. 12, pp. 2068-2073, 2008.

[7] M. A. Geidam, E. Dauda, and H. G. Hamza, "Effects of aqueous stem-bark extract of Momordica balsamina Linn on some serum enzymes in normal and ethanol fed rats," Journal of Biological Sciences, vol. 7, no. 2, pp. 397-400, 2007.

[8] H. N. Kamalkishor and H. N. Kulkarni, "Fish stupefying plants used by the Gond tribal of Mendha village of central India," Indian Journal of Traditional Knowledge, vol. 8, no. 4, pp. 531534, 2009.

[9] R. N. Chopra, R. L. Badhwar, and S. Ghosh, Poisonous Plants of India, Public Service Commission, Government of West Bengal, Calcutta, India, 1944.

[10] D. S. Seigler, "Piscicidal effect of some common plants in southwest Nigeria," Journal of Applied Science, vol. 5, no. 1, pp. 24172424, 2002.

[11] H. D. Neuwinger, "Plants used for poison fishing in tropical Africa," Toxicon, vol. 44, no. 4, pp. 417-430, 2004.

[12] O. O. Fafioye, "Plants with piscicidal activities in South Western Nigeria," Turkish Journal of Fisheries and Aquatic Sciences, vol. 5, pp. 91-97, 2005.

[13] S. Ahmed and M. Grainge, "Potential of the neem tree (Azadirachta indica) for pest control and rural development," Economic Botany, vol. 40, no. 2, pp. 201-209, 1986.

[14] D. P. Charkraborty, A. E. Nandy, and M. T. Philopose, "Barryingtonia acutangular (L.) Gaertin as a fish poison," Indian Journal of Experimental Biology, vol. 10, pp. 78-80, 1972.

[15] B. C. Onurusika and E. B. C. Ufodike, "Growth of African catfish, Clarias gariepinus (Tangels) subjected to sub-lethal concentrations of water extracts of Akee-apple, Blighia sapida and Kigelia africana," Journal of Aquatic Science, vol. 13, pp. 5962, 1998.

[16] J. N. Aguigwo, "Studies on Acute Toxicity of Cassava Leaf Extracts on African Catfish Clarias angiullaris," Journal of Aquatic Sciences, vol. 13, pp. 29-32, 1998.

[17] E. M. Obuotor and F. D. Onajobi, "Preliminary evaluation of cytotoxic properties of Raphia hookeri fruit mesocarp," Fitoterapia, vol. 71, no. 2, pp. 190-192, 2000.

[18] B. A. Ndon, The Raphia Palm: Economic Palm Series, Concept Publications, Lagos, Nigeria, 2003.

[19] M. C. Martínez, G. L. De Pinto, and C. Rivas, "Composition of Acacia macracantha gum exudates," Phytochemistry, vol. 31, no. 2, pp. 535-536, 1992.

[20] M. O. Otedoh, The systemic studies of Raphia palms [Ph.D. thesis], University of Reading, London, UK, 1976.

[21] M. O. Otedoh, "Sweet Raphia palm wine," The Nigerian Field, vol. 55, pp. 59-64, 1990.

[22] J. K. Ekelemu, "Preliminary studies on use of raphia palm ( $R a-$ phia hookeri) pulp to harvest fish and possible effects on fish production in the Niger Delta Area, Nigeria," Tropical Freshwater Biology, vol. 18, no. 1, 2009.

[23] A. O. Adeogun, "Haematological profiles of the African Clariid catfish (Clarias gariepinus) exposed to methanolic extract of Raphia hookeri," Tropical Veterinarian, vol. 29, no. 4, pp. 27-43, 2011.

[24] A. O. Adeogun, S. O. Fagade, and A. A. Adebisi, "Toxicity of the aqueous extracts of Raphia hookeri on two freshwater fin-fishes: Clarias gariepinus and Oreochromis niloticus," in Proceedings of SAN Conference, vol. 19, pp. 102-109, 1995.

[25] Food and Agriculture Organization (FAO), "Part 10: short term bio-assays," in Manual of Methods in Aquatic Environment Research, D. L. Reish and P. S. Oshida, Eds., FAO Fisheries Technical Paper 247, Food and Agriculture Organization (FAO) of the United Nations, Rome, Italy, 1987.

[26] APHA, Standard Methods for the Examination of Water and Waste Water, American Public Health Association, Washington, DC, USA, 16th edition, 1985.

[27] D. J. Finney, Probit Analysis, Cambridge University Press, Cambridge, UK, 3rd edition, 1971.

[28] E. A. Huisman and C. J. J. Richter, "Reproduction, growth, health control and aquacultural potential of the African catfish, Clarias gariepinus (Burchell 1822)," Aquaculture, vol. 63, no. 1-4, pp. 1-14, 1987.

[29] Y. Nahagama, "The functional morphology of Teleost gonads," in Fish Physiology, W. S. Hoar, D. T. Randall, and E. M. Donaldson, Eds., vol. 9, pp. 223-275, Academy Press, New York, NY, USA, 1983.

[30] W. T. R. Viveen, E. J. Ruhter, P. G. Van Oordt, A. L. Jane Ja, and E. A. Hisman, "Practical manual for culture of African Catfish, C. gariepinus," Translations of the Zoological Society of London, vol. 35, pp. 1-45, 1986.

[31] P. O. Aluko and M. H. Ali, "Production of eight types of fast growing intergeneric hybrids from four clariid species," Journal of Aquaculture in the Tropics, vol. 16, pp. 139-147, 2001.

[32] G. T. Ankley, K. M. Jensen, M. D. Kahl, J. J. Korte, and E. A. Makynen, "Description and evaluation of a short-term reproduction test with the fathead minnow (Pimephales promelas)," Environmental Toxicology and Chemistry, vol. 20, no. 6, pp. 1276-1290, 2001. 
[33] A. O. Adeogun, Effects of methanolic extracts of Raphia hookeri (Mann and Wendl) on life stages of Clarias gariepinus (Burchell, 1862) [Ph.D. thesis], University of Ibadan, Ibadan, Nigeria, 2004.

[34] A. O. Adeogun, "Acute toxicity of methanolic extract of Raphia hookeri on life stages of Clarias gariepinus," Journal of Science Research, vol. 11, no. 1, pp. 179-186, 2012.

[35] P. K. Roy, J. D. Munshi, and H. M. Dutta, "Effect of Saponin extracts on morpho-history and respiratory physiology of an air-breathing fish, Heteropneustes fossilis (Bloch," Journal of Freshwater Biology, vol. 2, pp. 135-145, 1990.

[36] G. Francis, H. P. S. Makkar, and K. Becker, "Antinutritional factors present in plant-derived alternate fish feed ingredients and their effects in fish," Aquaculture, vol. 199, no. 3-4, pp. 197227, 2001.

[37] G. Francis, Z. Kerem, H. P. S. Makkar, and K. Becker, “The biological action of saponins in animal systems: a review," British Journal of Nutrition, vol. 88, no. 6, pp. 587-605, 2002.

[38] L. He, Z. Guoying, Z. Huaiyun, and H. Yuanhao, "Chemical constituents and biological activities of saponin from the seed of Camellia oleifera," Scientific Research and Essays, vol. 5, no. 25, pp. 4091-4095, 2010.

[39] G. A. Thomas, Toxicity of Aqueous Extracts of the Stem of E. lateriflora on O. niloticus, Department of Zoology, University of Ibadan, 1998.

[40] C. Quist, Effects of Piper guineense on the blood, gills testes and gut of O. niloticus juveniles [M.S. thesis], Department of Zoology, University of Ibadan, 1992.

[41] V. I. Onwubuya, Comparative Study of the Toxicity of R. hookeri and Elephant Detergent on the Juvenile of $O$. niloticus $(L)$ and $C$ . gariepinus [M.S. thesis], Department of Zoology, University of Ibadan, 1999.

[42] P. Matthiessen and J. W. M. Logan, "Low concentration effects of endosulfan insecticide on reproductive behaviour in the tropical cichlid fish Sarotherodon mossambicus," Bulletin of Environmental Contamination and Toxicology, vol. 33, no. 5, pp. 575-583, 1984.

[43] W. B. Scott and J. Crossman, Freshwater Fishes of Canada, Fisheries Research Board of Canada, Ottawa, Canada, 1st edition, 1985.

[44] E. E. Little, J. F. Fairchild, and A. J. DeLoany, "Behavioural methods for assessing impacts of contaminants on early life stage fishes," in Proceedings of the American Fisheries Society Symposium, vol. 14, pp. 67-76, 1993.

[45] A. O. Adeogun and A. C. Victor, "Altered reproduction in Clarias gariepinus exposed to industrial effluents," American Journal of Agricultural and Biological Sciences, vol. 7, no. 1, pp. 61-70, 2012.

[46] S. Srivastava, P. Prabhakar, B. Singh, and B. C. Srivastava, "Toxicity and behavior of the fish Labeo rohita and Channa punctatus exposed to pulp and paper mill effluent," Journal of Ecotoxicology and Environmental Monitoring, vol. 17, pp. 241244, 2007.

[47] T. S. Pathan, P. B. Thete, S. E. Shinde, D. L. Sonawane, and Y. K. Khillare, "Histochemical changes in the liver of freshwater fish, Rasbora daniconius, exposed to paper mill effluent," Emirates Journal of Food and Agriculture, vol. 21, no. 2, pp. 263-266, 2009.

[48] A. O. Adeogun and A. V. Chukwuka, "Effect of textile factory effluent on otolith and somatic growth parameters in Clarias gariepinus," Zoologist, vol. 9, pp. 70-77, 2012.

[49] G. Fryer and T. D. Illis, The Cichlid Fishes of the Great Lakes of Africa: Their Biology and Evolution, Oliver and Boyd, Edinburg, Tex, USA, 1972.
[50] P. R. Parish, "Acute toxicity test," in Fundamentals of Aquatic Toxicology, G. M. Rand and S. R. Petrocelli, Eds., p. 666, Hemisphere Publishing Corporation, New York, NY, USA, 1985.

[51] G. M. Rand and S. R. Petrocelli, Fundamentals of Aquatic Toxicology, Hemisphere Publishing Corporation, New York, NY, USA, 1985.

[52] A. P. Vanerkar, S. Satyanarayan, and D. M. Dharmadhikari, "Toxicity of herbal pharmaceutical wastewater on fish-Lebistes reticulatus (Peter)," Journal of Environmental Science and Health B: Pesticides, Food Contaminants, and Agricultural Wastes, vol. 39, no. 1, pp. 115-123, 2004.

[53] A. S. Murthy, Toxicity of Pesticides to Fish, CRC Press, Boca Raton, Fla, USA, 1st edition, 1986.

[54] M. D. McCue, "Starvation physiology: reviewing the different strategies animals use to survive a common challenge," Comparative Biochemistry and Physiology, vol. 156, no. 1, pp. 1-18, 2010.

[55] W. H. Karasov, "Energetics, physiology and vertebrate ecology," Trends in Ecology and Evolution, vol. 1, no. 4, pp. 101-104, 1986.

[56] A. E. Dunham, B. W. Grant, and K. L. Overall, "Interfaces between biophysical and physiological ecology and the population ecology of terrestrial vertebrate ectotherms," Physiological Zoology, vol. 62, no. 2, pp. 335-355, 1989.

[57] K. A. Nagy, I. A. Girard, and T. K. Brown, "Energetics of freeranging mammals, reptiles, and birds," Annual Review of Nutrition, vol. 19, pp. 247-277, 1999.

[58] G. C. Whittow, Sturkie's Avian Physiology, Academic Press, San Diego, Calif, USA, 5th edition, 2000.

[59] S. Y. Sol, L. L. Johnson, T. K. Collier, M. M. Krahn, and U. Varanasi, "Contaminant effects on reproductive output in north Pacific flatfish," in Proceedings of the International Symposium on North Pacific Flatfish, Alaska Sea Grant Collection Program (NPFASGCP '95), pp. 547-560, Fairbanks, Alaska, USA, 1995.

[60] M. T. Shatunovskii, N. V. Akimova, and G. I. Ruban, "Response of reproductive systems of fishes to anthropogenic impacts," Journal of Ichthyology, vol. 36, pp. 242-256, 1996.

[61] C. M. Lye, C. L. J. Frid, M. E. Gill, and D. McCormick, "Abnormalities in the reproductive health of flounder Platichthys flesus exposed to effluent from a sewage treatment works," Marine Pollution Bulletin, vol. 34, no. 1, pp. 34-41, 1997.

[62] C. J. Rickwood, M. G. Dubé, L. M. Hewitt, T. G. Kovacs, and D. L. MacLatchy, "Use of paired fathead minnow (Pimephales promelas) reproductive test. Part 2: source identification of biological effects at a bleached kraft pulp mill," Environmental Toxicology and Chemistry, vol. 25, no. 7, pp. 1847-1856, 2006.

[63] C. J. Rickwood, M. G. Dubé, L. M. Hewitt, T. G. Kovacs, J. L. Parrott, and D. L. MacLatchy, "Use of paired fathead minnow (Pimephales promelas) reproductive test. Part 1: assessing biological effects of final bleached kraft pulp mill effluent using a mobile bioassay trailer system," Environmental Toxicology and Chemistry, vol. 25, no. 7, pp. 1836-1846, 2006.

[64] S. M. Wu, M.-J. Shih, and Y.-C. Ho, "Toxicological stress response and cadmium distribution in hybrid tilapia (Oreochromis sp.) upon cadmium exposure," Comparative Biochemistry and Physiology C: Toxicology and Pharmacology, vol. 145, no. 2, pp. 218-226, 2007.

[65] B. Jezierska, K. Lugowska, M. Witeska, and P. Sarnowski, "Malformations of newly hatched common carp larvae," Electronic Journal of Polish Agricultural Universities, vol. 3, pp. 12-19, 2000.

[66] F. Lahnsteiner and P. Patarnello, "The shape of the lipid vesicle is a potential marker for egg quality determination in the gilthead 
sea bream, Sparus aurata, and in the sharpsnout seabream, Diplodus puntazzo," Aquaculture, vol. 246, no. 1-4, pp. 423-435, 2005.

[67] E. Bonnet, A. Fostier, and J. Bobe, "Microarray-based analysis of fish egg quality after natural or controlled ovulation," $B M C$ Genomics, vol. 8, article 55, 2007.

[68] R. D. Robinson, Evaluation and development of laboratory protocol is for estimating reproductive impacts of pulp mill effluent on fish [Ph.D. thesis], University of Guelph, Ontario, Canada, 1994.

[69] T. G. Kovacs, J. S. Gibbons, L. A. Tremblay, B. I. O'Connor, P. H. Martel, and R. H. Voss, "The effects of a secondary-treated bleached kraft mill effluent on aquatic organisms as assessed by short-term and long-term laboratory tests," Ecotoxicology and Environmental Safety, vol. 31, no. 1, pp. 7-22, 1995.

[70] D. L. Borton, W. R. Streblow, T. M. Bousquet, and D. L. Cook, "Fathead minnow (Pimephales promeleas) reproduction during multigeneration life-cycle tests with kraft mill effluents," in Proceedings of the 4th International Conference on Environmental Impacts of the Pulp and Paper Industry Report 417, (EIPPIR '00), pp. 152-157, Finnish Environment Institute, Helsinki, Finland, 2000.

[71] D. L. Borton, W. R. Streblow, P. A. van Veld, T. J. Hall, and T. M. Bousquet, "Comparison of potential biomarkers to reproduction during fathead minnow (Pimephales promeleas) lifecycle tests with Kraft mill effluents," in Proceedings of the $3 \mathrm{rd}$ International Conference on the Environmental Fate and Effects of Pulp and Paper Mill Effluents, pp. 459-470, SETAC, Rotorua, New Zealand, 2003.

[72] L. M. Hewitt, T. G. Kovacs, M. G. Dubé et al., "Altered reproduction in fish exposed to pulp and paper mill effluents: roles of individual compounds and mill operating conditions," Environmental Toxicology and Chemistry, vol. 27, no. 3, pp. 682-697, 2008.

[73] S. L. Lamai, G. F. Warner, and C. H. Walker, "Effects of dieldrin on life stages of the African catfish, Clarias gariepinus (Burchell)," Ecotoxicology and Environmental Safety, vol. 42, no. 1, pp. 22-29, 1999.

[74] B. A. Sorensen, Ambient Toxicity Assessments of Clark Fork River Water-Toxicity Tests and Metals Residues in Brown Trout Organs, Montana Department of Fish wildlife and Parks, Helena, Mont, USA, 1991. 

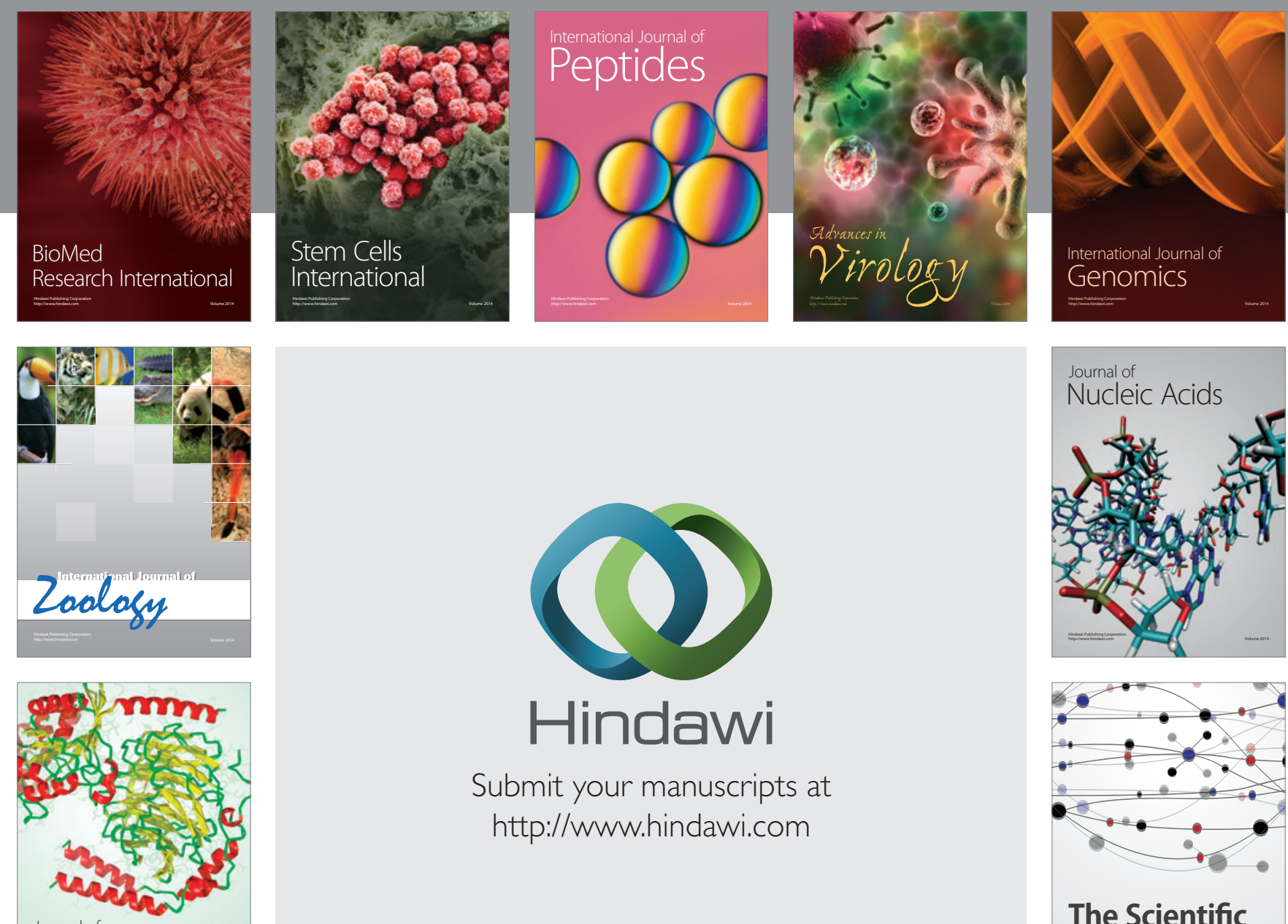

Submit your manuscripts at

http://www.hindawi.com

Journal of
Signal Transduction
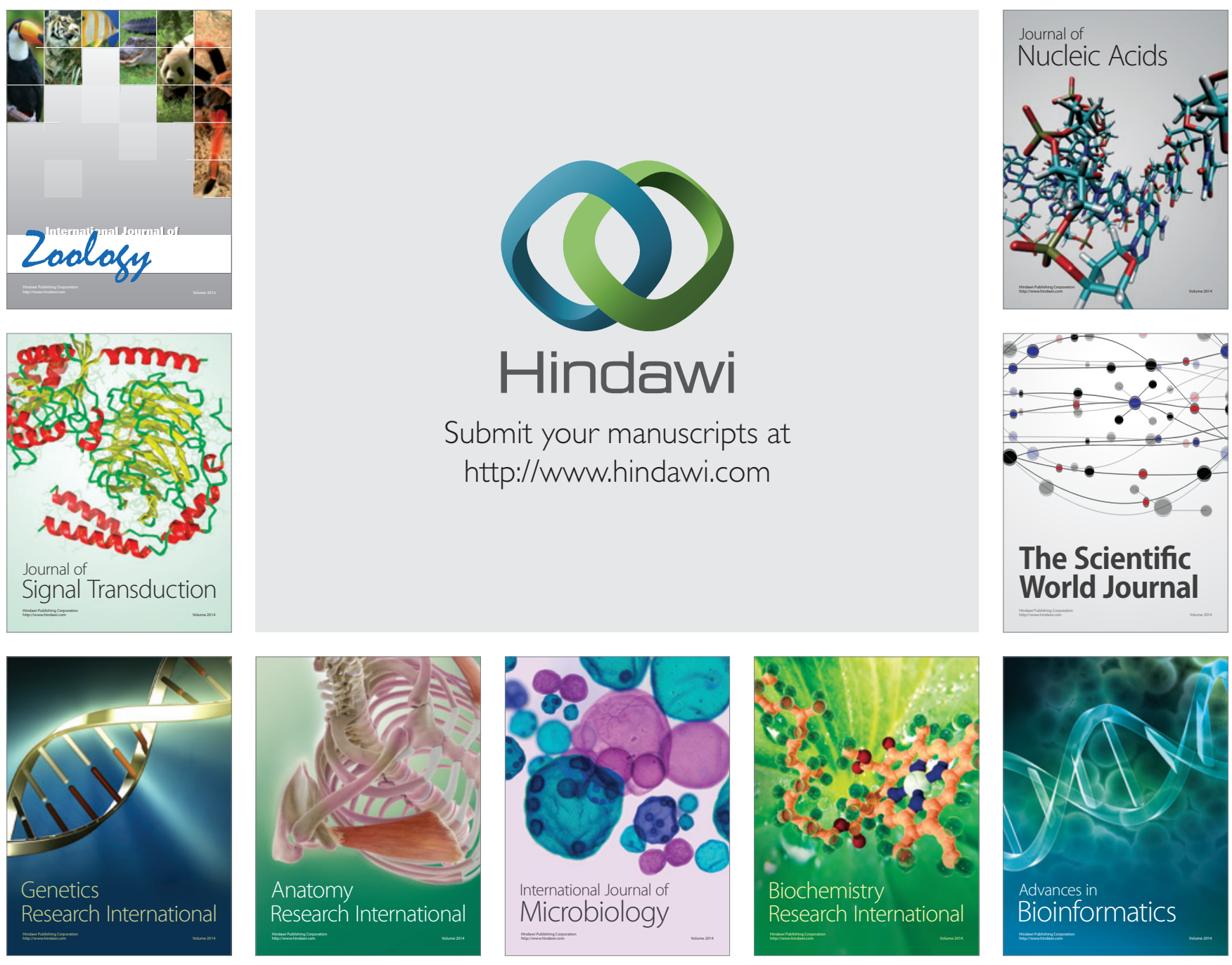

The Scientific World Journal
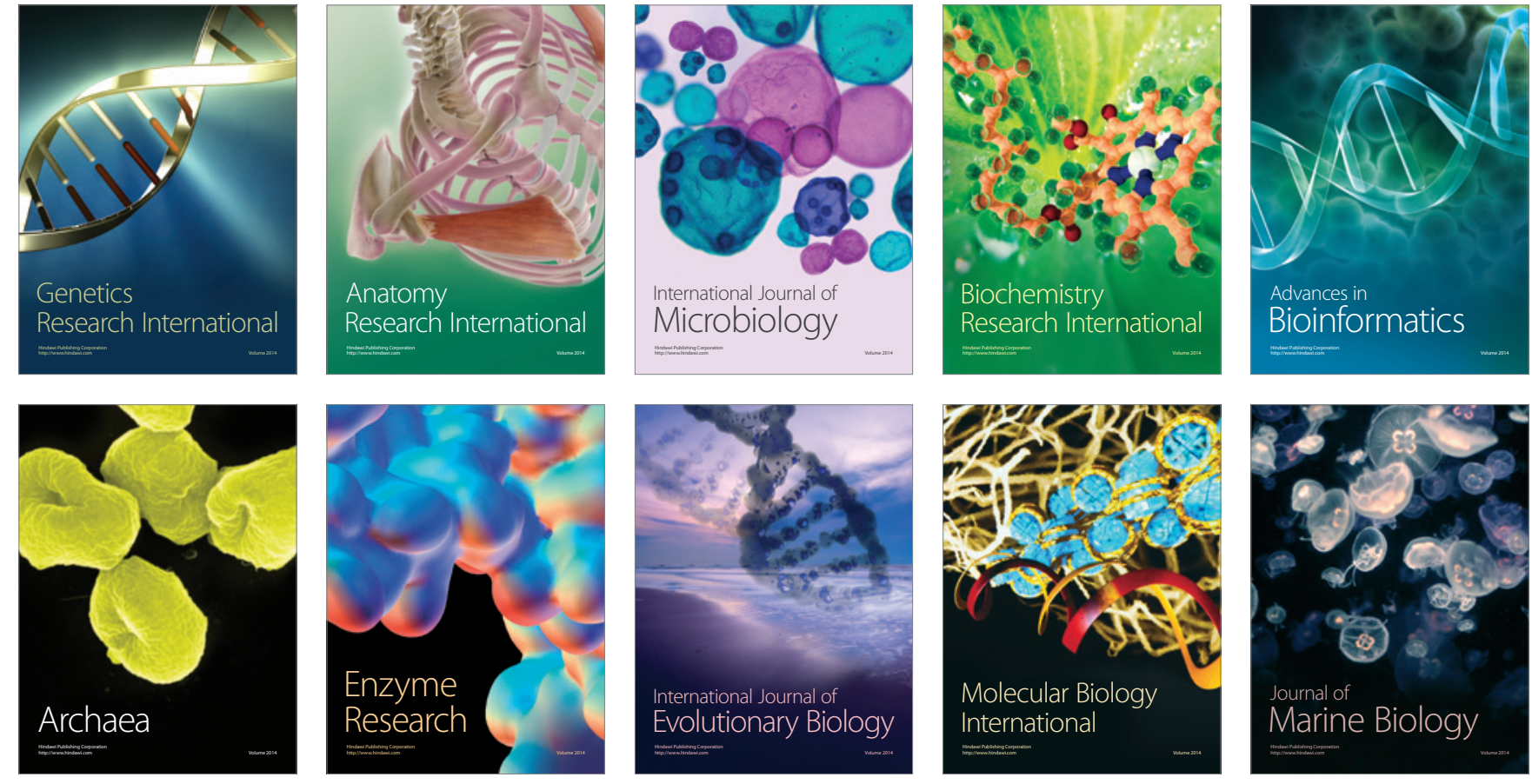